\title{
Resource Recovery from Waste Coffee Grounds Using Ultrasonic-Assisted Technology for Bioenergy Production
}

\author{
M. Mofijur ${ }^{1, *}$, F. Kusumo ${ }^{1,2}$, I. M. Rizwanul Fattah ${ }^{1}{ }^{D}$, H. M. Mahmudul ${ }^{3}$, M. G. Rasul $^{3}$, \\ A. H. Shamsuddin ${ }^{2}$ and T. M. I. Mahlia ${ }^{1}$ (D) \\ 1 School of Information, Systems and Modelling, Faculty of Engineering and Information Technology, \\ University of Technology Sydney, Ultimo, NSW 2007, Australia \\ 2 Institute of Sustainable Energy, Universiti Tenaga Nasional, Kajang 43000, Selangor, Malaysia \\ 3 School of Engineering and Technology, Central Queensland University, Rockhampton, QLD 4701, Australia \\ * Correspondence: MdMofijur.Rahman@uts.edu.au
}

Received: 12 March 2020; Accepted: 3 April 2020; Published: 7 April 2020

check for updates

\begin{abstract}
Biodiesel is a proven alternative fuel that can serve as a substitute for petroleum diesel due to its renewability, non-toxicity, sulphur-free nature and superior lubricity. Waste-based non-edible oils are studied as potential biodiesel feedstocks owing to the focus on the valorisation of waste products. Instead of being treated as municipal waste, waste coffee grounds (WCG) can be utilised for oil extraction, thereby recovering an energy source in the form of biodiesel. This study evaluates oil extraction from WCG using ultrasonic and Soxhlet techniques, followed by biodiesel conversion using an ultrasonic-assisted transesterification process. It was found that $n$-hexane was the most effective solvent for the oil extraction process and ultrasonic-assisted technology offers a 13.5\% higher yield compared to the conventional Soxhlet extraction process. Solid-to-solvent ratio and extraction time of the oil extraction process from the dried waste coffee grounds (DWCG) after the brewing process was optimised using the response surface methodology (RSM). The results showed that predicted yield of $17.75 \mathrm{wt}$. \% of coffee oil can be obtained using 1:30 w/v of the mass ratio of DWCG-ton-hexane and 34 min of extraction time when $32 \%$ amplitude was used. The model was verified by the experiment where $17.23 \mathrm{wt}$. \% yield of coffee oil was achieved when the extraction process was carried out under optimal conditions. The infrared absorption spectrum analysis of WCG oil determined suitable functional groups for biodiesel conversion which was further treated using an ultrasonic-assisted transesterification process to successfully convert to biodiesel.
\end{abstract}

Keywords: waste coffee grounds; ultrasonic-assisted technology; biodiesel; optimisation

\section{Introduction}

The limited reserves and increasing price of fossil fuels, as well as the adverse impact of fossil fuel combustion on climate change, has motivated researchers to find an alternative source of energy, e.g., renewable fuel sources [1-3]. Biodiesel is a renewable fuel consisting of a mixture of mono-alkyl esters and long-chain fatty acids, and is non-toxic, biodegradable and can be used in diesel engines with minimal modification [4-6]. Biodiesel is produced from different sources including edible oils, non-edible oils, and animal fats [7-11]. Currently, biodiesel production costs are calculated to be 4.4 times the cost of petroleum-derived diesel production [12]. Given that the current commercial biodiesel feedstocks are of edible oil origins such as palm and soy, government intervention in the biodiesel market will complicate the effects on food security. The use of WCG oil as biodiesel feedstock promotes biodiesel production from an alternative resource while reducing the issue of landfilling with food waste, which is prominent globally. 
Coffee is the world's second-largest traded liquid commodity, after oil, with approximately 8 million tons of coffee produced each year [13]. A large amount of heat energy is used to convert green coffee beans into brown roasted beans in the brewing process, generating large amounts of volatile organic compounds (VOCs) [14]. The enormous demand for this beverage also produces a large quantity of residual waste after brewing. Every 1 ton of coffee beans produces $650 \mathrm{~kg}$ of coffee residue after brewing, known as WCG [15]. The global coffee industry produced an estimate of 9.34 million tons of waste in 2017, which was either incinerated, dumped in landfills or composted [16]. Every year Australia produces an estimated 75,000 tonnes of used ground coffee waste, and 93\% of cafes send their WCGs to landfill. The annual domestic coffee consumption in Australia has reached almost 1.9 million $60 \mathrm{~kg}$ bags. On average, Australians consumed around 1.92 kilograms of coffee per person in 2017 [17]. The grounds that are used to make coffee are used only once and then immediately discarded. With rising rates of consumption, waste residues from the coffee industry (by-products from harvesting, processing, roasting and brewing stages of coffee production and processing) represent a challenge to worldwide directives aiming to reduce landfill volume. The inherent toxicity of several constituents within coffee also presents an environmental contamination concern [18]. Additionally, waste coffee grounds contribute towards the huge financial cost on taxpayers for running and maintaining landfills. Therefore, a combined solution of collection and reuse of WCG for alternate energy production would be beneficial to the coffee industry. WCG contains $15 \%-20 \%$ of lipid depending on the extraction technologies, which can be used as a source of bioenergy.

Production of oil from non-edible sources such as WCG can also help overcome the food versus fuel dispute [19]. The abundance of WCGs would also make it a readily available feedstock with a significantly lower production cost than edible oils [20]. WCG after oil extraction has also been identified as a suitable material for the production of garden fertiliser, feedstock for ethanol production, biogas production and fuel pellets [21]. However, the use of WCG oil for biodiesel production is still relatively new and requires further research before commercialisation.

This study aims to recover oil from WCG through an ultrasonic-assisted process and to convert it into biodiesel to reduce the volume of waste to landfill; reducing the greenhouse gas emissions associated with coffee waste in landfills. The WCG was subjected to ultrasonic-assisted oil extraction and compared with the Soxhlet extraction process before transesterification was used to produce WCG biodiesel by ultrasonication. The effect of extraction solvent, solvent to WCG ratio, ultrasonic power and ultrasonication period were studied to optimise oil extraction from the WCG. Further optimisation of parameters such as methanol to oil molar ratio, catalyst concentration, ultrasonic power and reaction time were done using Response Surface Methodology (RSM) to obtain the highest ester yield. RSM correlates the relationship between different response variables [22]. The effect of independent variables is determined by RSM which also creates a mathematical model which can be used for evaluating other relevant variables. The physicochemical properties of the obtained biodiesel were measured and compared with ASTM D6751 and EN 14214 biodiesel standards to determine its successful conversion to biodiesel [23-25].

\section{Materials and Methods}

WCG was obtained from a local store which was then oven-dried at $60^{\circ} \mathrm{C}$. High purity analytical grade chemicals (Sigma-Aldrich) and solvents including 2-propanol (purity 99.7\%), n-hexane (purity 99\%), methanol (purity 99.8\%), and potassium hydroxide were used to extract oil and convert into biodiesel.

\subsection{Moisture}

The moisture content of WCG was determined by measuring the mass before and after the drying of the collected samples. Drying was conducted in an electric oven (Tech-lab, stainless steel forced-air convection oven FAC-138SS) at $100^{\circ} \mathrm{C}$ for $36 \mathrm{~h}$. Mass of WCG was weighed before drying and at 
intervals of $12 \mathrm{~h}$. It was found that the mass stopped changing after $36 \mathrm{~h}$ which indicates the sample had dried. The following equation was used to determine the moisture content.

$$
\text { Moisture content }(\%)=\frac{\Delta m}{m_{i}} \times 100 \%
$$

where $\Delta m(\mathrm{~g})$ is the changes between the final and initial mass of the sample, $m_{i}(\mathrm{~g})$ is the initial mass of WCG.

The moisture content of WCG was found to be $20 \%$. For calculating more accurate oil yields, the mass of WCG was only weighed after the drying process. Table 1 shows the change of mass of WCG as drying time increases. Mass of WCG remained constant after the $24 \mathrm{~h}$ mark.

Table 1. Mass change of waste coffee grounds (WCG) with drying time.

\begin{tabular}{cc}
\hline Drying time (hours) & Mass $(\mathrm{g})$ \\
\hline 0 & 156 \\
12 & 130 \\
24 & 125 \\
36 & 125 \\
48 & 125 \\
\hline
\end{tabular}

\subsection{Experimental Setup}

The reactor used for Soxhlet extraction was equipped with a reflux condenser, one Soxhlet extractor, and a heating mantle. The temperature of the condenser was controlled using a refrigerator cooling bath WiseCircuß(Model: WCR-P8, Daihan Scientific, Gang-Won-Do, South Korea). The experimental setup of WCG Soxhlet extraction is illustrated in Figure 1a.

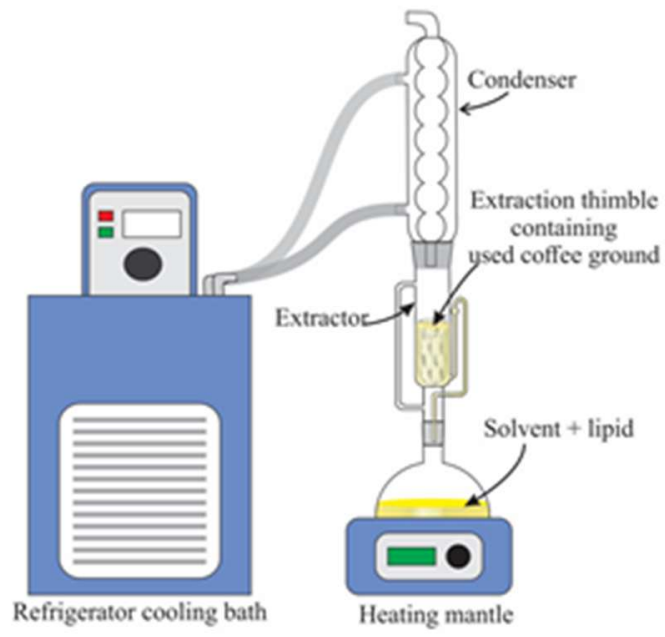

(a)

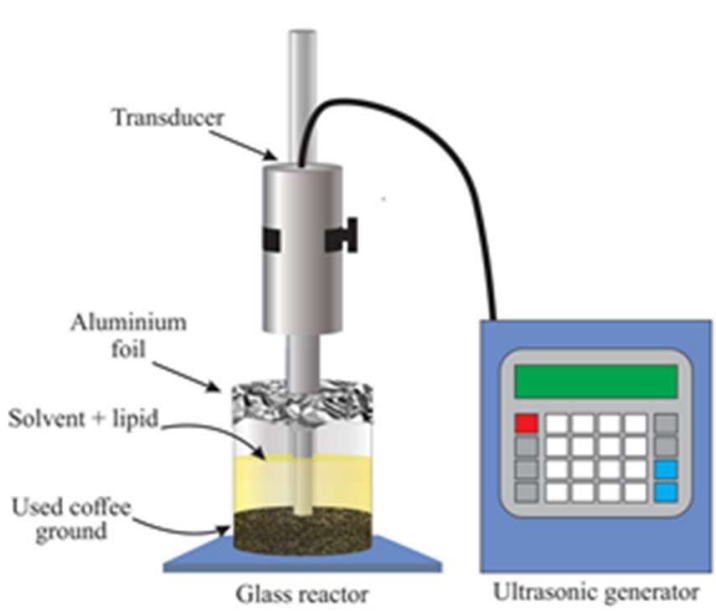

(b)

Figure 1. Schematic diagram of (a) Soxhlet extraction set-up, (b) ultrasonic-assisted extraction setup.

The equipment used for ultrasound extraction in this study was a Qsonica Q500-20 sonicator with a 1" diameter tip (500 W power rating, $20 \mathrm{kHz}$ frequency) ultrasonic probe. The sample was placed in $250 \mathrm{ml}$ beaker made of borosilicate glass as a reactor, where the tip of the probe was fully immersed in the solvent and sample mixture. The probe was placed in the center of the reactor to ensure even ultrasonication of the entire sample. The precaution was taken to ensure that the probe tip was fully immersed to ensure direct sonication of the sample. Figure $1 \mathrm{~b}$ shows a schematic of the ultrasonic-assisted extraction setup. The ultrasonication time, amplitude and frequency of ultrasonic waves can be changed using the sonicator system. However, the system was set at a moderate level to 
avoid energy wastage, deterioration of the sample, and to reduce risk of breaking of the equipment. The ultrasonication can also be set to continuous or pulsed modes. However, to increase the efficiency of the system, a pulsed mode was selected [26].

\subsection{Soxhlet Extraction Method}

In this step, $20 \mathrm{~g}$ of WCG was weighed in a cellulosic thimble before it was placed in a Soxhlet oil extractor. The oil was extracted using $300 \mathrm{ml}$ of three different types of organic solvents including $\mathrm{n}$-hexane, chloroform and methanol. Among the selected solvents, $\mathrm{n}$-hexane and chloroform are polar in nature whereas methanol is a non-polar solvent. The latent heat of vaporisation of chloroform is the lowest followed by the n-hexane and methanol solvents. These organic solvents increase the yield of oil extraction [27] compared to other green solvents. The average cycle time was recorded as $15 \mathrm{~min}$. To maintain this extraction cycle time, the temperature was varied based on the chosen solvent. The solvent-oil mixture was placed in a rotary evaporator (IKA RV 10 digital V rotary evaporator with vacuum) at $60^{\circ} \mathrm{C}$ to separate the extracted oil. The extraction process was done three times for each solvent type and the average oil extraction yield was calculated by measuring the mass of the dried sample.

\subsection{Ultrasonic-assisted Oil Extraction Method}

In this step, $10 \mathrm{~g}$ of WCG was poured into the $500 \mathrm{ml}$ beaker which also works as a reactor. Selected solvents including $\mathrm{n}$-hexane, chloroform or methanol were added at a ratio 1:20 $\mathrm{g} / \mathrm{ml}$ into ultrasonicator. The ultrasonic probe was immersed into a sample such that the tip was completely submerged in the solvent mixture. The ultrasonic waves were applied for $5 \mathrm{~s}$ with a stop interval of $2 \mathrm{~s}$. Extraction time $(25,37.6$, and $50 \mathrm{~min})$ and ultrasonic amplitude $(20 \%, 30 \%$, and $40 \%)$ were the other parameters selected for optimisation. The temperature was not selected for optimisation because of continuous compression and rarefaction of the ultrasonic cavitation cycle, which produces heat within the mixture. Filter papers were used for gravitation filtration of the solvent mixture from WCG oil. The rotary evaporator was used to evaporate the sample at $60^{\circ} \mathrm{C}$. The oil yield was calculated using Equation (2).

$$
\text { Oil yield percentage }=\frac{\text { mass of flask after exploration }- \text { mass of the empty flask }}{\text { mass of dried WCG }} \times 100 \%
$$

The molar mass of WCG oil was collected from literature as $862.8 \mathrm{~g} / \mathrm{mol}$ [28].

\subsection{Response Surface Methodology (RSM)}

Design-Expert software version 11 (Stat-Ease Inc., Minneapolis, USA) was used to analyse and optimise experimental data. Analysis of variance (ANOVA) and RSM features of the software were utilised. To optimise the parameters of the oil extraction process, Box-Behnken experimental design was applied. The operating parameters such as the amplitude (X1), reaction time (X2) and n-hexane (X3), were varied to optimise oil yield $(\mathrm{Y})$. The coded and uncoded levels of the Box-Behnken independent variables were presented in Table 2 . The experimental data were analysed in the form of a mathematical model as follows:

$$
Y=C_{0}+\sum_{i=1}^{k} C_{i} X_{i}+\sum_{i=1}^{k} C_{i i} X_{i}^{2}+\sum_{j=i+1}^{k} \cdot \sum_{i=1}^{k} C_{i j} X_{i j}
$$

where, $Y$ predicted the yield of WCG crude oil; $X i$ is the input independent parameter, $C_{\mathrm{o}}$ and $C i$ are the intercept and regression first-order coefficient of the model, regression coefficient among ith and jth input parameters, and the number of input parameters is represented by $k$ respectively. Cii is the regression quadratic coefficient of the model for the ith factor. Cij is the linear coefficient of the model for the interaction between the $i$ th and $j$ th factor. 
Table 2. Independent input process variables used for the optimisation of biodiesel yield.

\begin{tabular}{cccccc}
\hline \multirow{2}{*}{$\begin{array}{c}\text { Input Process } \\
\text { Variables }\end{array}$} & Units & Coded Factors & \multicolumn{2}{c}{ Coded Process Variables Levels } \\
\cline { 4 - 5 } & & & $\mathbf{- 1}$ Level & Center & $\mathbf{+ 1}$ Level \\
\hline Amplitude & $\%$ & $X_{1}$ & 20 & 30 & 40 \\
Reaction time & min & $X_{2}$ & 25 & 37.5 & 50 \\
n-hexane & $\%$ & $X_{3}$ & 15 & 22.5 & 30 \\
\hline
\end{tabular}

\subsection{Two-Step Esterification and Transesterification}

The methyl ester was produced using a two-step esterification and trans-esterification process. The esterification process was carried out due to extracted oil having a very high acid value. In this process, the WCG crude oil sample was transferred into a reactor and then mixed with methanol at a molar ratio of $6: 1$ (methanol to oil). A 1 vol. $\% \mathrm{H}_{2} \mathrm{SO}_{4}$ catalyst was added into the pre-heated oil $\left(60^{\circ} \mathrm{C}\right)$. An ultrasonication amplitude of $30 \%$ was applied for 60 to $105 \mathrm{~min}$. The ultrasonic waves were applied for $5 \mathrm{~s}$ with 2-s rest intervals. Following the esterification process, the sample was transferred into a separating funnel. Two distinguishable liquid layers were observed, the top layer consisted of catalyst residues and methanol whereas the bottom layer contained esterified WCG oil.

The esterified oil was placed in a reactor. The required amount of catalyst $\mathrm{KOH}$ was weighed into a beaker along with methanol for mixing. Before pouring into the reactor, the mixture was heated and stirred up until the $\mathrm{KOH}$ pellets were completely dissolved. The ultrasonic probe was immersed into the mixture in a way that ensured the tip was fully submerged inside the solvent mixture. A similar procedure for ultrasonication as of esterification was followed. The transesterification process was carried out with $1 \mathrm{w} / \mathrm{wt} \% \mathrm{KOH}$ in $6: 1$ methanol to oil ratio for 30, 45, 60 and $75 \mathrm{~min}$, as a part of the optimisation of reaction time. The temperature was not optimised for the reason explained previously. After transesterification, the separation was carried out by allowing the mixture to settle. The bottom layer (glycerol layer) was removed before washing off the top layer. Washing was done with warm water $\left(60^{\circ} \mathrm{C}\right)$ several times until no impurities were observed in the water. The biodiesel was then placed in a rotary evaporator to remove any remaining moisture. The top biodiesel layer was tested for fatty acid methyl ester (FAME) contents using the Agilent 7890A Gas Chromatograph (GC). Figure 2 shows the phase separation after transesterification.

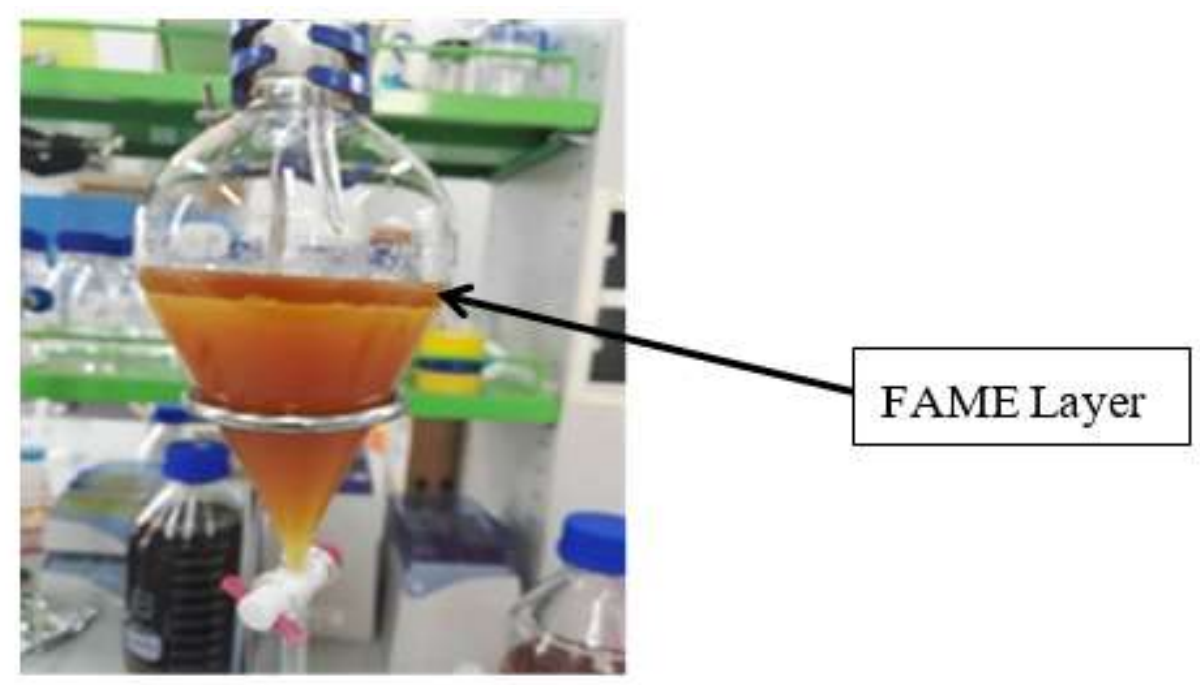

Figure 2. Phase separation after transesterification.

\subsection{The GC Analysis of the Fatty Acid Composition (FAC)}

A GC (Agilent 7890A) fitted with a flame ionisation detector was used to determine the FAME content of the produced biodiesel. Carbon chains (C8-C24) in the FAME layer and linolenic acid 
methyl ester content of the biodiesel were measured following the EN 14103:2011 standard method with methyl nonadecanoate (internal standard). This method is suitable for use with the GC equipped with HP-INNOWax high-polarity column (length $\times$ inner diameter $\times$ film thickness: $30 \mathrm{~m} \times 0.25 \mathrm{~mm}$ $\times 0.25 \mu \mathrm{m}$, stationary phase: polyethylene glycol). The oven temperature protocol: $2 \mathrm{~min}$ constant $60{ }^{\circ} \mathrm{C}$, heated to $200{ }^{\circ} \mathrm{C}$ at $10{ }^{\circ} \mathrm{C}$ increase per minute, then to $240{ }^{\circ} \mathrm{C}$ at $5{ }^{\circ} \mathrm{C}$ increase per minute and finally $7 \mathrm{~min}$ at $240^{\circ} \mathrm{C}$. Helium gas was used as the carrier gas, with a flow rate for helium of $1.5 \mathrm{~mL} / \mathrm{min}$. All the FAMEs were chromatographically resolved at the approximate retention time of 25 min. The comparison between the area of methyl ester peaks and internal standard peaks provided the FAME yield (Equation (4)):

$$
E=\frac{\left(\sum A\right)-A_{E l}}{A_{E l}} \times \frac{W_{E l}}{m} \times 100 \%
$$

where $E$ signifies the percentage FAME content (\%), $\sum A$ the sum of the area of C8:0 to C24:0 peaks, $A_{E l}$ the peak area of internal standards, $W_{E l}$ the weight $(\mathrm{mg})$ of methyl nonadecanoate and $\mathrm{m}$ is the weight (mg) of the sample.

\subsection{FT-IR Analysis}

The characterisation of WCG methyl ester was carried out by FT-IR (Perkin Elmer equipped with the MIR TGS detector) in the range $4000-650 \mathrm{~cm}^{-1}$ and analysed with the software program 'Spectrum'. The resolution was 8 scans and between $8 \mathrm{~cm}^{-1}$ and $4 \mathrm{~cm}^{-1}$.

\section{Results and Discussions}

\subsection{Comparison of Soxhlet and Ultrasonic-Assisted Extraction}

From Table 3, the WCG reaction time was found to be $30 \mathrm{~min}$ with the highest oil yield obtained being $15.84 \%$ using ultrasound-assisted extraction. As for Soxhlet extraction, the highest yield was found to be $15.62 \%$ at $180 \mathrm{~min}$ reaction time. It is seen that for the constant solvent, ultrasonic-assisted extraction technology offers a higher oil yield and takes less time to complete compared to Soxhlet technology.

Table 3. Comparison of WCG oil yield of Soxhlet and ultrasonic-assisted extraction process.

\begin{tabular}{cccc}
\hline Method & Time (min) & n-hexane & Yield (\%) \\
\hline \multirow{3}{*}{ Ultrasound } & 20 & $1: 20$ & 13.73 \\
& 30 & $1: 20$ & 15.84 \\
& 40 & $1: 20$ & 14.82 \\
\hline \multirow{3}{*}{ Soxhlet } & 60 & $1: 20$ & 8.9 \\
& 120 & $1: 20$ & 12.74 \\
& 180 & $1: 20$ & 15.62 \\
\hline
\end{tabular}

\subsection{Effect of Solvent on Lipid Extraction Yield}

Results on the effect of solvents on lipid extraction showed that $\mathrm{n}$-hexane offers the highest yield (15.8\%) followed by, chloroform (12.3\%) and methanol (9.11\%). Reshad [29] reported improved performance of n-hexane for rubber seed oil extraction. Al-Hammare et al. [30] also obtained a higher oil yield (15.3\%) when using the Soxhlet technique and n-hexane solvent. Although the oil yield is higher than that reported in this study, this may be due to the nature of the source from which the WCG was obtained. Oil extraction using methanol resulted in $18.67 \%$ more viscous oil than $\mathrm{n}$-hexane which might be the result of non-oil components being extracted together with the oil components due to its polarity, as suggested by Perrier [31]. Further, due to the alcohol's low selectivity to triglycerides, the extraction will involve other compounds such as polyphenols, phosphatides, soluble sugars and 
pigments [32]. An ethanol and chloroform solvent mixture were found to produce the highest oil yield for microalgae Chlorella sp. [33]. This suggests that the selection of solvent for oil extraction depends on the feedstock used. It is to be noted that effective oil extraction requires complete solvent penetration into oil storage and matching targeted compounds polarity [34].

\subsection{Optimisation of the WCG Oil Yield Using Response Surface Methodology}

In this study, WCG oil yield was maximised by optimising the independent process variables, such as amplitude, reaction time and amount of $n$-hexane. The quadratic regression model was suggested after a regression analysis performed on Box-Behnken experimental design results. The WCG oil yield results for 17 experimental runs obtained using the quadratic regression model equation are shown in Table 4.

Table 4. Experimental design for the optimisation WCG extraction process.

\begin{tabular}{cccccc}
\hline Run & $\mathbf{X}_{\mathbf{1}}$ Amplitude & $\mathbf{X}_{\mathbf{2}}$ Time & $\mathbf{X}_{\mathbf{3}} \mathbf{n}$-hexane & Experiment Yield & Predicted Yield \\
\hline 1 & 20 & 37.5 & 15 & 11.6 & 11.53 \\
2 & 40 & 37.5 & 30 & 16.44 & 16.51 \\
3 & 40 & 37.5 & 15 & 13.03 & 12.99 \\
4 & 30 & 25 & 30 & 17.28 & 17.32 \\
5 & 40 & 25 & 22.5 & 15.22 & 15.11 \\
6 & 20 & 25 & 22.5 & 13.18 & 13.10 \\
7 & 30 & 37.5 & 22.5 & 16.42 & 16.49 \\
8 & 20 & 37.5 & 30 & 14.22 & 14.26 \\
9 & 30 & 37.5 & 22.5 & 16.57 & 16.49 \\
10 & 30 & 37.5 & 22.5 & 16.52 & 16.49 \\
11 & 20 & 50 & 22.5 & 12.53 & 12.64 \\
12 & 30 & 50 & 15 & 13.6 & 14.57 \\
13 & 30 & 25 & 15 & 14.13 & 16.79 \\
14 & 30 & 50 & 22.5 & 16.94 & 16.49 \\
15 & 30 & 37.5 & 22.5 & 16.38 & 16.49 \\
16 & 30 & 37.5 & 22.5 & 16.56 & 14.34 \\
17 & 40 & 50 & & 14.26 & \\
\hline
\end{tabular}

The WCG oil yield is predicted by the quadratic model in the form of coded values is shown in Equation (5).

$$
\begin{array}{r}
Y=-17.18125+1.364 X_{1}+0.229 X_{2}+0.5017 X_{3}-0.00062 X_{1} X_{2}+0.00263 X_{1} X_{3}+0.000507 X_{2} X_{3} \\
-0.0217875 X_{1}^{2}-0.003288 X_{2}^{2}-0.00869 X_{3}^{2}
\end{array}
$$

Here, $Y$ shows the WCG oil yield and $X_{1}, X_{2}$ and $X_{3}$ exhibit the amplitude, reaction time, and amount of n-hexane.

The significance of the response surface model (quadratic) to optimise the WCG oil yield was evaluated using ANOVA. The results are presented in Table 5. The quadratic model p-value was also $<0.0001$, which indicated that the quadratic regression model was "significant". Model terms are significant if values of "Prob $>F^{\prime}$ " are less than 0.0500 and model terms are insignificant if values of "Prob $>$ F" are greater than 0.10. The lack of fit "F value" is 0.0927 , which indicates that lack of fit was not significant relative to the pure error. The value R2 is 0.9975 , which indicates that $99.75 \%$ of the deviation in USC crude oil yield was due to independent input process variables chosen for this model. According to high $\mathrm{R}^{2}$ value, data points will be closer to the regression line, and it was a better estimation between the experimental data and quadratic model. 
Table 5. Analysis of variance results for a quadratic regression model.

\begin{tabular}{ccccccc}
\hline Source & $\begin{array}{c}\text { Sum of } \\
\text { Squares }\end{array}$ & $\begin{array}{c}\text { Degree of } \\
\text { Freedom }\end{array}$ & Mean & F-Value & $p$-Value & \\
\hline Model & 50.81 & 9 & 5.65 & 313.92 & $<0.0001$ & Significant \\
$\mathrm{X}_{1}$-Amplitude & 6.88 & 1 & 6.88 & 382.64 & $<0.0001$ & \\
$\mathrm{X}_{2}$-Time & 0.7688 & 1 & 0.7688 & 42.75 & 0.0003 & \\
$\mathrm{X}_{3}$-n-hexane & 19.59 & 1 & 19.59 & 1089.41 & $<0.0001$ & \\
$\mathrm{X}_{1} \mathrm{X}_{2}$ & 0.0240 & 1 & 0.0240 & 1.34 & 0.2857 & \\
$\mathrm{X}_{1} \mathrm{X}_{3}$ & 0.1560 & 1 & 0.1560 & 8.67 & 0.0215 & \\
$\mathrm{X}_{2} \mathrm{X}_{3}$ & 0.0090 & 1 & 0.0090 & 0.5018 & 0.5016 & \\
$\mathrm{X}_{1}^{2}$ & 19.99 & 1 & 19.99 & 1111.28 & $<0.0001$ & \\
$\mathrm{X}_{2}^{2}$ & 1.11 & 1 & 1.11 & 61.79 & 0.0001 & \\
$\mathrm{X}_{3}^{2}$ & 1.01 & 1 & 1.01 & 55.92 & 0.0001 & \\
Residual & 0.1259 & 7 & 0.0180 & & & \\
Lack of Fit & 0.0967 & 3 & 0.0322 & 4.42 & 0.0927 & not significant \\
Pure Error & 0.0292 & 4 & 0.0073 & & & \\
Cor Total & 50.94 & 16 & & & & \\
\hline
\end{tabular}

The calculated yield of WCG oil at the optimal condition of 1:30 g/g of the mass of oil: n-hexane for $34 \mathrm{~min}$ of reaction time at the $32 \%$ amplitude was $17.75 \mathrm{wt}$. \%. The yield of calculated coffee oil under the optimal condition can be proved by the experiment. The results from the experiment showed that $17.23 \mathrm{wt}$. \% of coffee oil can be extracted from WCG under the optimal condition. Thus, the experimental yield closely matches the calculated coffee oil yield.

\subsubsection{Effect of Ultrasonic Amplitude and Period on WCG Lipid Yield}

As ultrasonication amplitude increases bubble collapse becomes more violent, which leads to higher extraction yields. However, an excessive ultrasonic amplitude may lead to wastage of energy. The WCG oil extraction versus ultrasonic amplitude and period is shown in Figure 3a,b. With the use of n-hexane solvent, the increase of amplitude from $20 \%$ to $33 \%$ resulted in a significant increase in oil extraction. The ultrasonic power increase in this range enhances the molecular diffusion of oil into the n-hexane. However, the extraction yield decreases after this amplitude. Liu et al. [35] reported a reduction of oil yield after a specific ultrasonic power threshold and attributed this to intense heating resulting in decomposition and volatility of the oil. The optimum condition resulted in an oil extraction of $17.75 \mathrm{wt}$. \% using ultrasonic assistance, significantly higher than that obtained using the Soxhlet extraction method. For rapeseed oil extraction, Sicaire et al. [36] reported that the chief contributors to optimised oil yield were ultrasonic intensity and solvent-to-solid ratio. They also reported a reduction of oil yield when ultrasonic power exceeded the optimum values $(>30 \%)$. 


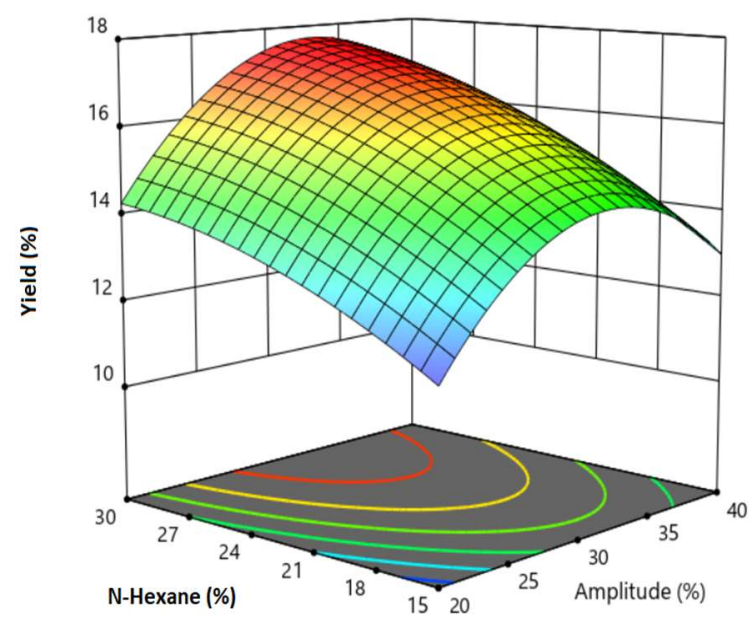

(a)

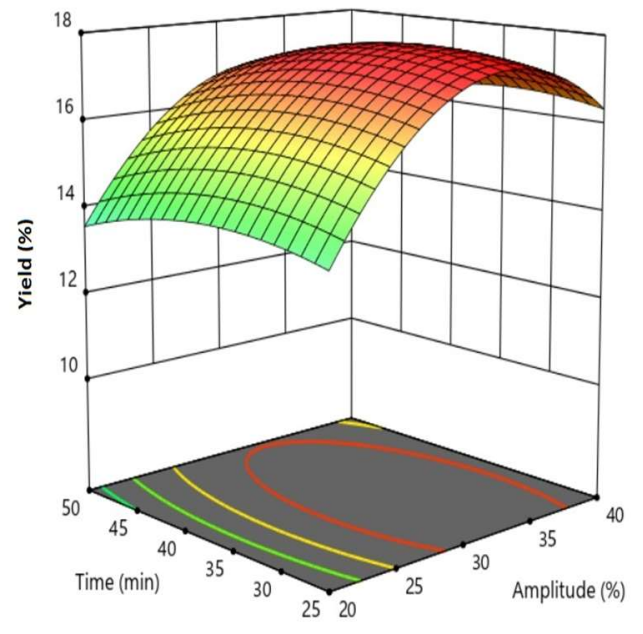

(b)

Figure 3. Three-dimensional surface plot of (a) n-hexane vs amplitude, (b) time vs amplitude.

The optimum extraction period avoids excessive power use and reduces the risk of oil damage. Sufficient extraction time is required to break ground coffee cell walls, extract the lipids and achieve an equilibrium [37]. From the results, the optimum ultrasonic oil extraction period using n-hexane was $34 \mathrm{~min}$, significantly lower than the $3 \mathrm{~h}$ required by the Soxhlet extraction method for the same solvent. Thus, the oil is not subjected to intense heating for long periods which reduces the risk of oil degradation [38]. Zhang et al. [39] reported a similar optimum extraction period for flaxseed oil. The initial rapid oil extraction rate is due to the solvent penetration into the cellular structure at a faster rate. Due to the oil constituents' external diffusion through the porous residual solids, a reduced extraction rate at a later stage was observed [40]. Evaporation might have resulted in the loss of a large portion of solvent which reduced the extraction efficiency. WCG cell wall rupture results in suspended impurities within the extract which may reduce the permeability of solvent into cell structure [41]. Furthermore, the extended periods of ultrasonication might also result in WCG oil re-adsorbing into ruptured tissue particles due to the larger specific surface area [42].

\subsubsection{Effect of Amount of n-hexane on Lipid Extraction Yield}

Figure 4 shows a 3D plot of the reaction time versus the amount of n-hexane. From the results, the optimum n-hexane for WCG ultrasonic oil extraction is 1:30. High extraction rates require a high amount of n-hexane, but extended extraction periods, in turn, increase energy consumption as well as the chance of degradation of extracted oil. 


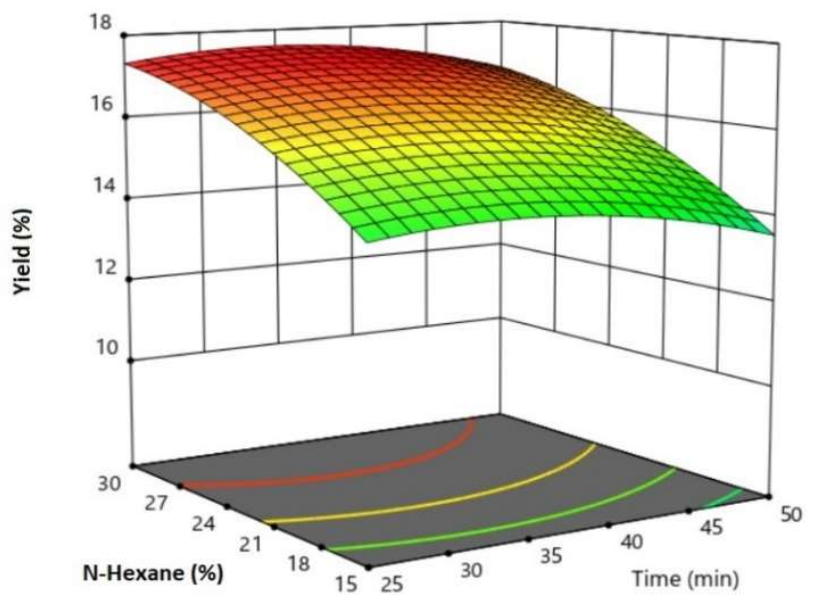

Figure 4. Three-dimensional surface plot of n-hexane vs time.

\subsection{Properties of Recovered Lipid}

The acid value of ultrasonically extracted WCG oil was $9.56 \mathrm{mg} \mathrm{KOH} / \mathrm{g}$ oil. The viscosity and density of the oil were determined to be $43.6 \mathrm{~mm}^{2} / \mathrm{s}$ and $918.4 \mathrm{~kg} / \mathrm{m}^{3}$ respectively. The WCG oil higher heating value (HHV) was measured to be $38.85 \mathrm{MJ} / \mathrm{kg}$, exceeding the HHV of other biodiesel feedstocks such as waste cooking oil [43], cottonseed oil [44] and rice bran oil [45]. The higher calorific value might be due to the high carbon to oxygen ratios [46].

\subsection{Esterification and Transesterification Process}

To reduce the total energy required for oil extraction, the ultrasonic amplitude was optimised. Figure 5 depicts WCG fatty acid methylester (FAME) yield after different periods. The FAME yield continues to increase up to $60 \mathrm{~min}$ reaction time reaching a peak $(98.21 \%)$ before slightly reducing beyond $60 \mathrm{~min}$ reaction time. Ultrasonic assistance is known to reduce the reaction time for biodiesel conversion. The $60 \mathrm{~min}$ reaction time required using ultrasonic assistance is significantly lower compared to conventional solvent transesterification of WCG (12 h for optimum conversion) [35]. Temperature and time affect the transesterification reaction as it is kinetically controlled. Temperature changes during long sonication periods have been known to destroy the oil [47]. It is also challenging to maintain the temperature throughout the ultrasonication process due to the constant compression and rarefactions, resulting in a temperature which fluctuates. By controlling the reaction period, the total amount of energy introduced into the system can be easily quantified. Furthermore, given the large heat capacities of certain oils, the effect temperature has during the transesterification reaction is small when compared to the time [48]. Extended reaction times would decrease FAME yields due to degradation and polymerisation [49]. 


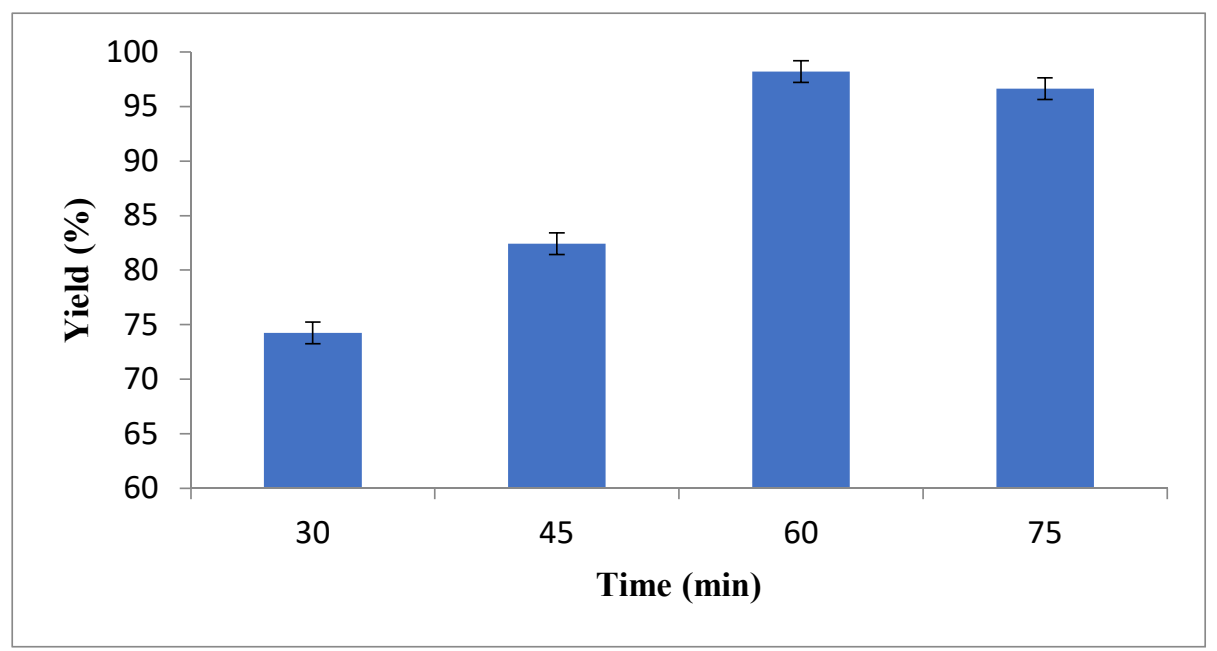

Figure 5. Relationship between biodiesel yield and reaction time.

\subsection{Characterisation of FAME of WCG}

\subsubsection{GC Analysis}

The FAC was determined via GC following the steps described in the methodology section. WCG biodiesel is known to have a similar FAC to corn and soybean biodiesel [50]. The FAME profile for the biodiesel produced optimally is reported in Table 6.

Table 6. FAC of WCG biodiesel.

\begin{tabular}{|c|c|c|c|c|}
\hline Fatty Acids & Molecular Weight & Structure & Formula & wt. $\%$ \\
\hline Myristic acid & 228 & 14:0 & $\mathrm{C}_{14} \mathrm{H}_{28} \mathrm{O}_{2}$ & 3.82 \\
\hline Myristoleic & 226 & $14: 1$ & $\mathrm{C}_{14} \mathrm{H}_{26} \mathrm{O}_{2}$ & 20 \\
\hline Palmitic & 256 & $16: 0$ & $\mathrm{C}_{16} \mathrm{H}_{32} \mathrm{O}_{2}$ & 19 \\
\hline Stearic & 284 & 18:0 & $\mathrm{C}_{18} \mathrm{H}_{36} \mathrm{O}_{2}$ & 6.73 \\
\hline Oleic & 282 & $18: 1$ & $\mathrm{C}_{18} \mathrm{H}_{34} \mathrm{O}_{2}$ & 9.27 \\
\hline Linoleic & 280 & $18: 2$ & $\mathrm{C}_{18} \mathrm{H}_{32} \mathrm{O}_{2}$ & 28.71 \\
\hline Arachidic & 312 & $20: 0$ & $\mathrm{C}_{20} \mathrm{H}_{40} \mathrm{O}_{2}$ & 2.96 \\
\hline Tricosanoic & 338 & $23: 0$ & $\mathrm{C}_{23} \mathrm{H}_{46} \mathrm{O}_{2}$ & 5.11 \\
\hline Lignoceric & 368 & $24: 1$ & $\mathrm{C}_{24} \mathrm{H}_{46} \mathrm{O}_{2}$ & 4.29 \\
\hline \multicolumn{4}{|c|}{ Total saturated fatty acid } & 37.61 \\
\hline \multicolumn{4}{|c|}{ Total monounsaturated fatty acid (MUFA) } & 33.56 \\
\hline \multicolumn{4}{|c|}{ Total polyunsaturated fatty acid (PUFA) } & 28.71 \\
\hline
\end{tabular}

As shown in Table 6, WCG biodiesel has 37.61\% saturated fatty acids and $62.27 \%$ unsaturated fatty acids, the latter of which consists of $33.56 \%$ monounsaturated fatty acids and $28.71 \%$ polyunsaturated fatty acids. Among the fatty acids linoleic (18:2) is the predominant fatty acid compared to other fatty acids.

\subsubsection{FT-IR Analysis}

The characteristic peaks of the WCG methyl ester are found at $2926 \mathrm{~cm}^{-1}, 2854 \mathrm{~cm}^{-1}, 1743 \mathrm{~cm}^{-1}$, $1435-1463 \mathrm{~cm}^{-1}$ and $1163 \mathrm{~cm}^{-1}$, which corresponds to the $\mathrm{C}-\mathrm{H}$ stretching vibration with strong absorption intensity, $\mathrm{CH} 2$ asymmetric and symmetric vibration with strong absorption intensity, $\mathrm{C}=\mathrm{O}$ stretching vibration with strong absorption intensity, $\mathrm{CH} 2$ shear-type vibration with mild absorption intensity, and $\mathrm{C}-\mathrm{O}-\mathrm{C}$ symmetric stretching vibration with mild absorption intensity, respectively. Table 7 shows the characteristic peaks of WCG methyl ester. 
Table 7. Characteristic peaks of WCG in FT-IR spectra.

\begin{tabular}{ccc}
\hline Absorption Bands $\left(\mathbf{c m}^{-\mathbf{1}}\right)$ & Functional Group & Absorption Intensity \\
\hline 2926 & C-H stretching vibration & Strong \\
2854 & $\mathrm{CH} 2$ asymmetric and symmetric vibration & Strong \\
1743 & C = O stretching vibration & Strong \\
$1435-1463$ & CH2 shear type vibration & Middling \\
1163 & C-O-C symmetric stretching vibration & Middling \\
\hline
\end{tabular}

\subsubsection{Physicochemical Property Analysis}

The fuel properties of WCG biodiesel produced through ultrasonic transesterification were analysed and compared to the ASTM D6751 and EN 14214 standards [51]. Table 8 shows the fuel properties of WCG FAME. It was found that the kinematic viscosity of WCG FAME was $4.89 \mathrm{~mm}^{2} / \mathrm{s}$, the higher heating value was $39.74 \mathrm{MJ} / \mathrm{kg}$, density was $886.8 \mathrm{~kg} / \mathrm{m}^{3}$ and the acid value lowered to $0.52 \mathrm{mgKOH} / \mathrm{g}$ oil. Further, the ester content was found at $98.21 \%$. However, all these results except the acid value were within the specified limit of the ASTM D6751 and EN14214 standards.

Table 8. Properties of WCG methyl ester.

\begin{tabular}{cccc}
\hline Properties & WCG Biodiesel & ASTM D6751 & EN 14214 \\
\hline Ester content $(\%)$ & 97 & - & Minimum 96.5 \\
Acid value $\left(\mathrm{mg} \mathrm{KOH} \mathrm{g}^{-1}\right)$ & 0.52 & Maximum 0.5 & Maximum 0.5 \\
Kinematic viscosity at $40^{\circ} \mathrm{C}\left(\mathrm{mm}^{2} / \mathrm{s}\right)$ & 4.89 & 1.9 to 6.0 & 3.5 to 5.0 \\
Density at $15^{\circ} \mathrm{C}\left(\mathrm{kg} / \mathrm{m}^{3}\right)$ & 886.8 & 880 & 860 to 900 \\
Higher heating value $(\mathrm{MJ} / \mathrm{kg})$ & 39.74 & - & - \\
\hline
\end{tabular}

\section{Conclusions}

This paper evaluated the recovery of an energy source from a wasted product, i.e., waste coffee grounds, using ultrasonic assistance to produce biodiesel. Use of this feedstock is advantageous as it is abundant, utilises a food waste, and eliminates the side effects of landfill disposal. Some of the salient results are:

Successful production of biofuel oil from the UCG using ultrasonic assistance which was later converted into biodiesel.

The optimum ultrasonic oil extraction conditions were $1: 30 \mathrm{~g} / \mathrm{g}$ of the mass ratio of oil-to-n-hexane, $32 \%$ ultrasonic amplitude with a reaction time of $34 \mathrm{~min}$ and an achieved oil yield of $17.75 \mathrm{wt} . \%$.

Ultrasonication of WCG during oil extraction reduced the amount of solvent required significantly. This also reduced extraction time and increased extractability compared to the conventional Soxhlet extraction method.

Thus, the study can suggest ultrasonic assistance is a superior method compared to the Soxhlet extraction method. Furthermore, it is also possible to convert waste-to-energy by producing biodiesel from WCG. Further studies are required to evaluate the produced biodiesel as a substitute for petro-diesel.

Author Contributions: Conceptualization, M.M.; methodology, F.K.; formal analysis, I.M.R.F.; investigation, F.K.; writing — original draft preparation, M.M.; writing—review and editing, H.M.M. and M.G.R.; supervision, T.M.I.M. and A.H.S. All authors have read and agreed to the published version of the manuscript.

Funding: This research was funded by research development fund of School of Information, Systems and Modelling, University of Technology Sydney, Australia. This research also received financial support from AAIBE Chair of Renewable Energy (Grant no: 201801 KETTHA).

Conflicts of Interest: The authors declare no conflict of interest. 


\section{References}

1. Bhuiya, M.M.K.; Rasul, M.; Khan, M.; Ashwath, N.; Mofijur, M. Comparison of oil extraction between screw press and solvent (n-hexane) extraction technique from beauty leaf (Calophyllum inophyllum L.) feedstock. Ind. Crops Prod. 2020, 144, 112024. [CrossRef]

2. Mofijur, M.; Mahlia, T.M.I.; Silitonga, A.S.; Ong, H.C.; Silakhori, M.; Hasan, M.H.; Putra, N.; Rahman, S.M.A. Phase Change Materials (PCM) for Solar Energy Usages and Storage: An Overview. Energies 2019, $12,3167$. [CrossRef]

3. Uddin, M.; Techato, K.; Taweekun, J.; Rahman, M.; Rasul, M.; Mahlia, T.; Ashrafur, S. An Overview of Recent Developments in Biomass Pyrolysis Technologies. Energies 2018, 11, 3115. [CrossRef]

4. Mofijur, M.; Masjuki, H.H.; Kalam, M.A.; Atabani, A.E. Evaluation of biodiesel blending, engine performance and emissions characteristics of Jatropha curcas methyl ester: Malaysian perspective. Energy 2013, 55, 879-887. [CrossRef]

5. Mofijur, M.; Masjuki, H.H.; Kalam, M.A.; Atabani, A.E.; Fattah, I.M.R.; Mobarak, H.M. Comparative evaluation of performance and emission characteristics of Moringa oleifera and Palm oil based biodiesel in a diesel engine. Ind. Crops Prod. 2014, 53, 78-84. [CrossRef]

6. Shahabuddin, M.; Liaquat, A.M.; Masjuki, H.H.; Kalam, M.A.; Mofijur, M. Ignition delay, combustion and emission characteristics of diesel engine fueled with biodiesel. Renew. Sustain. Energy Rev. 2013, 21, $623-632$. [CrossRef]

7. Mahlia, T.M.I.; Syazmi, Z.A.H.S.; Mofijur, M.; Abas, A.E.P.; Bilad, M.R.; Ong, H.C.; Silitonga, A.S. Patent landscape review on biodiesel production: Technology updates. Renew. Sustain. Energy Rev. 2020, 118, 109526. [CrossRef]

8. Ong, H.C.; Masjuki, H.H.; Mahlia, T.M.I.; Silitonga, A.S.; Chong, W.T.; Yusaf, T. Engine performance and emissions using Jatropha curcas, Ceiba pentandra and Calophyllum inophyllum biodiesel in a CI diesel engine. Energy 2014, 69, 427-445. [CrossRef]

9. Ong, H.C.; Milano, J.; Silitonga, A.S.; Hassan, M.H.; Shamsuddin, A.H.; Wang, C.T.; Mahlia, T.M.I.; Siswantoro, J.; Kusumo, F.; Sutrisno, J. Biodiesel production from Calophyllum inophyllum-Ceiba pentandra oil mixture: Optimization and characterization. J. Clean. Prod. 2019, 219, 183-198. [CrossRef]

10. Silitonga, A.; Shamsuddin, A.; Mahlia, T.; Milano, J.; Kusumo, F.; Siswantoro, J.; Dharma, S.; Sebayang, A.; Masjuki, H.; Ong, H.C. Biodiesel synthesis from Ceiba pentandra oil by microwave irradiation-assisted transesterification: ELM modeling and optimization. Renew. Energy 2020, 146, 1278-1291. [CrossRef]

11. Silitonga, A.S.; Masjuki, H.H.; Mahlia, T.M.I.; Ong, H.C.; Chong, W.T.; Boosroh, M.H. Overview properties of biodiesel diesel blends from edible and non-edible feedstock. Renew. Sustain. Energy Rev. 2013, 22, 346-360.

12. Fazeli Danesh, A.; Ebrahimi, S.; Salehi, A.; Parsa, A. Impact of nutrient starvation on intracellular biochemicals and calorific value of mixed microalgae. Biochem. Eng. J. 2017, 125, 56-64. [CrossRef]

13. Döhlert, P.; Weidauer, M.; Enthaler, S. Spent coffee ground as source for hydrocarbon fuels. J. Energy Chem. 2016, 25, 146-152. [CrossRef]

14. Allesina, G.; Pedrazzi, S.; Allegretti, F.; Tartarini, P. Spent coffee grounds as heat source for coffee roasting plants: Experimental validation and case study. Appl. Therm. Eng. 2017, 126, 730-736. [CrossRef]

15. Murthy, P.S.; Madhava Naidu, M. Sustainable management of coffee industry by-products and value addition-A review. Resour. Conserv. Recycl. 2012, 66, 45-58. [CrossRef]

16. Zabaniotou, A.; Kamaterou, P. Food waste valorization advocating Circular Bioeconomy-A critical review of potentialities and perspectives of spent coffee grounds biorefinery. J. Clean. Prod. 2019, 211, 1553-1566. [CrossRef]

17. Cameron, A.; O'Malley, S. Coffee Ground Recovery Program Summary Report. Available online: https: //planetark.org/documents/doc-1397-summary-report-of-feasibility-study-april-2016.pdf (accessed on 30 December 2019).

18. Kookos, I.K. Technoeconomic and environmental assessment of a process for biodiesel production from spent coffee grounds (SCGs). Resour. Conserv. Recycl. 2018, 134, 156-164. [CrossRef]

19. Palconite, C.L.; Edrolin, A.C.; Lustre, S.N.B.; Manto, A.A.; Caballero, J.R.L.; Tizo, M.S.; Ido, A.L.; Arazo, R.O. Optimization and characterization of bio-oil produced from Ricinus communis seeds via ultrasonic-assisted solvent extraction through response surface methodology. Sustain. Environ. Res. 2018, 28, 444-453. [CrossRef] 
20. Gui, M.M.; Lee, K.; Bhatia, S. Feasibility of edible oil vs. non-edible oil vs. waste edible oil as biodiesel feedstock. Energy 2008, 33, 1646-1653. [CrossRef]

21. Atabani, A.E.; Shobana, S.; Mohammed, M.N.; Uğuz, G.; Kumar, G.; Arvindnarayan, S.; Aslam, M.; Al-Muhtaseb, A.A.H. Integrated valorization of waste cooking oil and spent coffee grounds for biodiesel production: Blending with higher alcohols, FT-IR, TGA, DSC and NMR characterizations. Fuel 2019, 244, 419-430. [CrossRef]

22. Dharma, S.; Masjuki, H.H.; Ong, H.C.; Sebayang, A.H.; Silitonga, A.S.; Kusumo, F.; Mahlia, T.M.I. Optimization of biodiesel production process for mixed Jatropha curcas-Ceiba pentandra biodiesel using response surface methodology. Energy Convers. Manag. 2016, 115, 178-190. [CrossRef]

23. Jamaluddin, N.A.M.; Riayatsyah, T.M.I.; Silitonga, A.S.; Mofijur, M.; Shamsuddin, A.H.; Ong, H.C.; Mahlia, T.M.I.; Rahman, S.M.A. Techno-economic analysis and physicochemical properties of Ceiba pentandra as second-generation biodiesel based on ASTM D6751 and EN 14214. Processes 2019, 7, 636. [CrossRef]

24. Coh, B.H.H.; Ong, H.C.; Cheah, M.Y.; Chen, W.H.; Yu, K.L.; Mahlia, T.M.I. Sustainability of direct biodiesel synthesis from microalgae biomass: A critical review. Renew. Sustain. Energy Rev. 2019, 107, 59-74.

25. Silitonga, A.S.; Mahlia, T.M.I.; Kusumo, F.; Dharma, S.; Sebayang, A.H.; Sembiring, R.W.; Shamsuddin, A.H. Intensification of Reutealis trisperma biodiesel production using infrared radiation: Simulation, optimisation and validation. Renew. Energy 2019, 133, 520-527. [CrossRef]

26. Hashemi, S.M.B.; Michiels, J.; Asadi Yousefabad, S.H.; Hosseini, M. Kolkhoung (Pistacia khinjuk) kernel oil quality is affected by different parameters in pulsed ultrasound-assisted solvent extraction. Ind. Crops Prod. 2015, 70, 28-33. [CrossRef]

27. Tan, C.H.; Nagarajan, D.; Show, P.L.; Chang, J.-S. Chapter 25-Biodiesel From Microalgae. In Biofuels: Alternative Feedstocks and Conversion Processes for the Production of Liquid and Gaseous Biofuels, 2nd ed.; Pandey, A., Larroche, C., Dussap, C.-G., Gnansounou, E., Khanal, S.K., Ricke, S., Eds.; Academic Press: Cambridge, MA, USA, 2019; pp. 601-628.

28. Rocha, M.V.P.; de Matos, L.J.B.L.; Lima, L.P.d.; Figueiredo, P.M.d.S.; Lucena, I.L.; Fernandes, F.A.N.; Gonçalves, L.R.B. Ultrasound-assisted production of biodiesel and ethanol from spent coffee grounds. Bioresour. Technol. 2014, 167, 343-348. [CrossRef]

29. Reshad, A.S.; Tiwari, P.; Goud, V.V. Extraction of oil from rubber seeds for biodiesel application: Optimization of parameters. Fuel 2015, 150, 636-644. [CrossRef]

30. Al-Hamamre, Z.; Foerster, S.; Hartmann, F.; Kröger, M.; Kaltschmitt, M. Oil extracted from spent coffee grounds as a renewable source for fatty acid methyl ester manufacturing. Fuel 2012, 96, 70-76. [CrossRef]

31. Perrier, A.; Delsart, C.; Boussetta, N.; Grimi, N.; Citeau, M.; Vorobiev, E. Effect of ultrasound and green solvents addition on the oil extraction efficiency from rapeseed flakes. Ultrason. Sonochemistry 2017, 39, 58-65. [CrossRef]

32. Baümler, E.R.; Carrín, M.E.; Carelli, A.A. Extraction of sunflower oil using ethanol as solvent. J. Food Eng. 2016, 178, 190-197. [CrossRef]

33. Ramluckan, K.; Moodley, K.G.; Bux, F. An evaluation of the efficacy of using selected solvents for the extraction of lipids from algal biomass by the soxhlet extraction method. Fuel 2014, 116, 103-108. [CrossRef]

34. Adeoti, I.A.; Hawboldt, K. A review of lipid extraction from fish processing by-product for use as a biofuel. Biomass Bioenergy 2014, 63, 330-340. [CrossRef]

35. Liu, P.; Xu, Y.-f.; Gao, X.-d.; Zhu, X.-y.; Du, M.-z.; Wang, Y.-x.; Deng, R.-x.; Gao, J.-y. Optimization of ultrasonic-assisted extraction of oil from the seed kernels and isolation of monoterpene glycosides from the oil residue of Paeonia lactiflora Pall. Ind. Crops Prod. 2017, 107, 260-270. [CrossRef]

36. Sicaire, A.-G.; Vian, M.A.; Fine, F.; Carré, P.; Tostain, S.; Chemat, F. Ultrasound induced green solvent extraction of oil from oleaginous seeds. Ultrason. Sonochemistry 2016, 31, 319-329. [CrossRef] [PubMed]

37. Son, J.; Kim, B.; Park, J.; Yang, J.; Lee, J.W. Wet in situ transesterification of spent coffee grounds with supercritical methanol for the production of biodiesel. Bioresour. Technol. 2018, 259, 465-468. [CrossRef]

38. Chen, X.; Luo, Y.; Qi, B.; Wan, Y. Simultaneous extraction of oil and soy isoflavones from soy sauce residue using ultrasonic-assisted two-phase solvent extraction technology. Sep. Purif. Technol. 2014, 128, 72-79. [CrossRef]

39. Zhang, Z.-S.; Wang, L.-J.; Li, D.; Jiao, S.-S.; Chen, X.D.; Mao, Z.-H. Ultrasound-assisted extraction of oil from flaxseed. Sep. Purif. Technol. 2008, 62, 192-198. [CrossRef] 
40. Goula, A.M. Ultrasound-assisted extraction of pomegranate seed oil-Kinetic modeling. J. Food Eng. 2013, 117, 492-498. [CrossRef]

41. Tian, Y.; Xu, Z.; Zheng, B.; Martin Lo, Y. Optimization of ultrasonic-assisted extraction of pomegranate (Punica granatum L.) seed oil. Ultrason. Sonochemistry 2013, 20, 202-208. [CrossRef]

42. Dong, J.; Liu, Y.; Liang, Z.; Wang, W. Investigation on ultrasound-assisted extraction of salvianolic acid B from Salvia miltiorrhiza root. Ultrason. Sonochemistry 2010, 17, 61-65. [CrossRef]

43. Madheshiya, A.K.; Vedrtnam, A. Energy-exergy analysis of biodiesel fuels produced from waste cooking oil and mustard oil. Fuel 2018, 214, 386-408. [CrossRef]

44. Shankar, A.A.; Pentapati, P.R.; Prasad, R.K. Biodiesel synthesis from cottonseed oil using homogeneous alkali catalyst and using heterogeneous multi walled carbon nanotubes: Characterization and blending studies. Egypt. J. Pet. 2017, 26, 125-133. [CrossRef]

45. Mazaheri, H.; Ong, H.C.; Masjuki, H.H.; Amini, Z.; Harrison, M.D.; Wang, C.-T.; Kusumo, F.; Alwi, A. Rice bran oil based biodiesel production using calcium oxide catalyst derived from Chicoreus brunneus shell. Energy 2018, 144, 10-19. [CrossRef]

46. Kelkar, S.; Saffron, C.M.; Chai, L.; Bovee, J.; Stuecken, T.R.; Garedew, M.; Li, Z.; Kriegel, R.M. Pyrolysis of spent coffee grounds using a screw-conveyor reactor. Fuel Process. Technol. 2015, 137, 170-178. [CrossRef]

47. Bahmani, L.; Aboonajmi, M.; Arabhosseini, A.; Mirsaeedghazi, H. Effects of ultrasound pre-treatment on quantity and quality of essential oil of tarragon (Artemisia dracunculus L.) leaves. J. Appl. Res. Med. Aromat. Plants 2018, 8, 47-52. [CrossRef]

48. Lee, S.B.; Lee, J.D.; Hong, I.K. Ultrasonic energy effect on vegetable oil based biodiesel synthetic process. J. Ind. Eng. Chem. 2011, 17, 138-143. [CrossRef]

49. Thiruvenkadam, S.; Izhar, S.; Hiroyuki, Y.; Harun, R. One-step microalgal biodiesel production from Chlorella pyrenoidosa using subcritical methanol extraction (SCM) technology. Biomass Bioenergy 2019, 120, $265-272$. [CrossRef]

50. Efthymiopoulos, I.; Hellier, P.; Ladommatos, N.; Mills-Lamptey, B. Transesterification of high-acidity spent coffee ground oil and subsequent combustion and emissions characteristics in a compression-ignition engine. Fuel 2019, 247, 257-271. [CrossRef]

51. Silitonga, A.S.; Masjuki, H.H.; Ong, H.C.; Sebayang, A.H.; Dharma, S.; Kusumo, F.; Siswantoro, J.; Milano, J.; Daud, K.; Mahlia, T.M.I.; et al. Evaluation of the engine performance and exhaust emissions of biodiesel-bioethanol-diesel blends using kernel-based extreme learning machine. Energy 2018, 159, 1075-1087. [CrossRef]

(C) 2020 by the authors. Licensee MDPI, Basel, Switzerland. This article is an open access article distributed under the terms and conditions of the Creative Commons Attribution (CC BY) license (http://creativecommons.org/licenses/by/4.0/). 